\title{
北海道産アライグマの寄生蠕禷
}

\author{
浅川 満彦 ${ }^{1)}$, 倉 地 徹 ${ }^{1)}$, 酪農学園大学野生動物生態研究会 ${ }^{2)}$ \\ 1）酪農学園大学獣医学部寄生虫学教室 $=069-8501$ 北海道江別市文京台緑町 582-1 \\ 2）酪農学園大学文化系サークル テ 069-0831 北海道江別市野幌若葉町 92-1 夢喰庵
} (1999.2.15 受付, 1999.7.12 受理)

\section{Parasitic Helminths of Raccons in Hokkaido, Japan}

\author{
Mitsuhiko ASAKAWA ${ }^{1)}$, Tohru KURACHI ${ }^{1)}$ and Wildlife Ecological Society ${ }^{2)}$ \\ 1) Department of Parasitology, Faculty of Veterinary Medicine, Rakuno Gakuen \\ University, Ebetsu, Hokkaido 069-0836, Japan \\ 2) Bakuan, Nopporo-Wakaba-cho, Ebetsu, Hokkaido 069-0831, Japan
}

\begin{abstract}
An investigation of the parasitic helminths in 61 feral and 7 captive individuals of raccoons, Procyon lotor, collected in Hokkaido, Japan, was done, and Toxocara tanuki(Ascarididae: Nematoda) [Number of raccoons positively infected:1], Metagonimus takahashii (Heterophyidae: Trematoda) [2] and Euparyphium sp. (Echinostomatidae: Trematoda) [7], were obtained from the feral raccoons. This is the first record of these helminth species from this host species.
\end{abstract}

Key Words: Metagonimus takahashii, Procyon lotor, Toxocara tanuki, Euparyphium sp., Japan

Jpn.J.Zoo Wildl.Med. 4(2) : 101-103, 1999

北海道各地では, 現在, 北米原産のアライグマProcyon lotor が野生化し, 農産物に甚大な被害をもたらしている [1]。また公衆衛生学的には, アライグマ蜔虫 Baylisascaris procyonis による幼虫移行症が欧米で報告されており [2-4]，日本でも展示・飼育個体から同線虫が発見されてい る $[5]$ 。

そこで, 今回, 1995 年 9 月から 1998 年 11 月にかけて, 北 海道石狩低地带の長沼町, 江別市, 由仁町, 千歳市, 恵庭 市および札幌市で駆除あるいは交通事故死した野生の 61 個体と北海道大学文学部で飼育されていたものを深麻酔に より安楽死した 7 個体, 合計 68 個体のアライグマについ て，その消化管を含む諸臟器とあるいは消化管のみを材料 に寄生蠕虫類を調查した。

検出された吸虫類は, 圧扁後 70\%エタノールで固定後, カーミン染色を施し, エタノールで脱水, キシレンで透徹 後, カナダバルサムで封入し, 永久プレパラート標本とし た。線䗰も $70 \%$ エタノールで固定後, ラクトフェノール
液で透徹した。これらの標本を光学顕微鏡で観察し, 一部 は顕微鏡撮影装置を用いて写真撮影をした。

札幌市羊が丘の 1 個体から蜔虫類（図 1 4）が，また長 沼町の 1 個体および千歳市の 1 個体から異形吸虫科の Metagonimus 属の吸虫（図 5) が, さらに長沼町の 5 個体 および千歳市の 2 個体から棘口吸虫科の吸虫（図 6 および 7)がそれぞれ発見された。今回, Metagonimus 属の吸虫が 検出された個体ではすべて棘口吸虫科の吸虫も混合感染し ていた。これらの蠕虫類の寄生部位はすべて小腸であった。 他の 60 個体からは，寄生蠕虫類は見つからなかった。

今回の蛔虫類を, Hartwich[6]の検索表に基づき同定し たところ，食道後部に胃部が認められること，しかしその 胃部には付属的な盲端部を欠くこと, 副交接刺を欠くこと， 腸盲囊を欠くこと，間唇を欠くこと，アライグマ蜔虫など に見られる総排泄口付近の微細乳頭群が見られなかったこ とから, Ascarididaeの Toxocarinae, Toxocara 属である ことが判明した。また，交接刺が長いことから，タヌキ 
浅川満彦ら

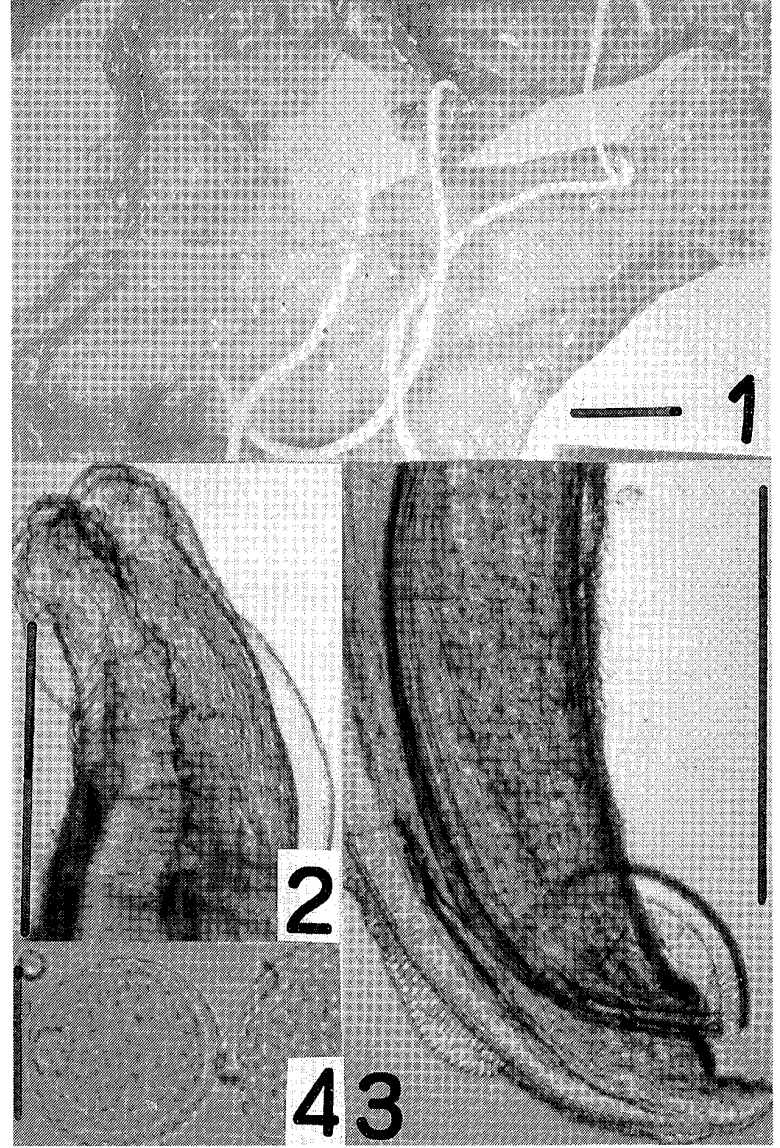

図 1〜4 札幌市で駆除されたアライグマから検出された狸 蜔虫

1：小腸寄生の様子（スケールは $10 \mathrm{~mm}$ )

2 : 頭部（スケールは $0.5 \mathrm{~mm}$ )

$3 ：$ ア尾部右側（スケールは $1 \mathrm{~mm}$ )

$4:$ 子宮内虫卵（スケールは $50 \mu \mathrm{m}$ )

Nyctereutes procyonoidesですでに報告のある狸蜔虫 Toxocara tanuki Yamaguti,1941［7］であると同定され た。

Skrjabin ら[8]の総説によると，同属の犬蜔虫 Toxocara canis がアライグマから記録されているが，猖蜔虫が夕ヌ キ以外の動物から発見されたことはない。狸蜔虫の場合も， 他の Toxocara 属の蜔虫類と同様に, 含幼虫卵の経口的摄 取により感染が成立すると考元られる。今回のアライグマ における寄生も，当該アライグマが摂食した飳が，蜔虫卵 を含む夕ヌキ䔬便に污染されたことにより感染が成立した と推測された。

日本列島とその周辺地域には Metagonimus 属の吸虫が 6 種知られているが $[9]$, 今回の虫卵の長径平均值が $31 \mu m$

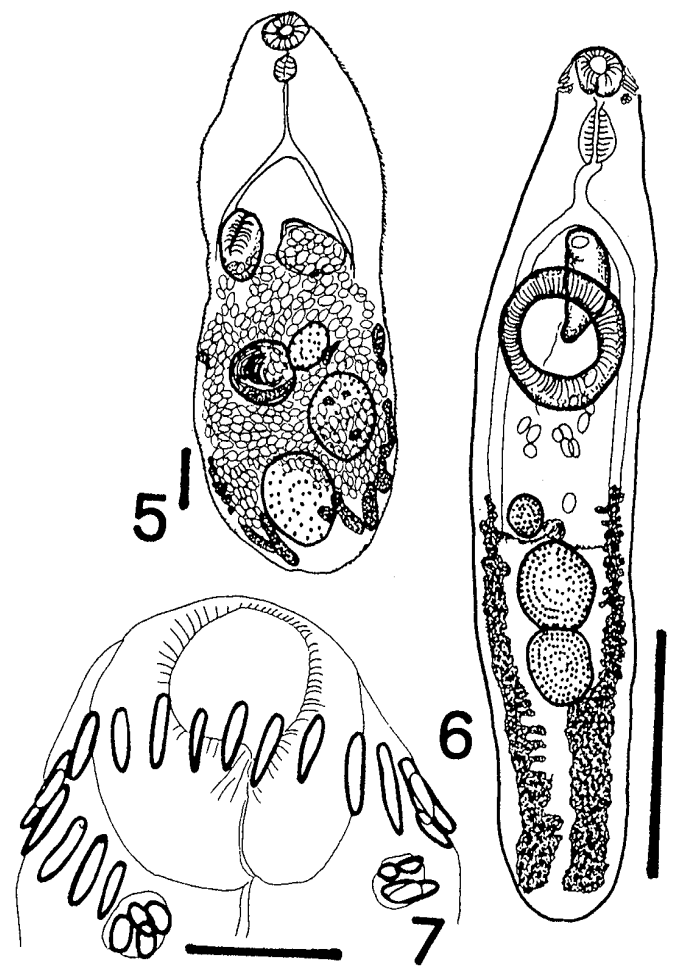

図 5〜7 北海道長沼町および千歳市で駆除されたアライグマ から検出された吸虫類 2 種

$5:$ 高橋吸虫（スケールは $0.1 \mathrm{~mm})$

6:Euparyphium sp.の全体像（スケールは $1 \mathrm{~mm}$ )

7 : 同・頭部（スケールは $0.1 \mathrm{~mm}$ )

であったこと，口吸盤が生殖腹吸盤より大きいこと，子宮 が左右精巣の間から体後縁部にまで分布すること，右卵黄 腺が右精巣後部にまで達したことが，高橋吸虫 $M$. t t $k a$ hashii の特徵 [9] と一致した。

これまでのところ，アライグマからは原産地の北米では 異形吸虫科の Metagonimoides oregonensis や Phagicola angrenseなどが報告されているが [10-13]，高橋吸虫が検 出されたのは初めてであった。

Schell の検索表 [14］に従うと，今回検出された棘口吸 虫科の成熟虫体長が約 $3 \mathrm{~mm}$ と短いこと, 体型が細長く腹 吸盤が体中央部前方に位置すること，陰茎囊が短く腹吸盤 の後部に達しないこと, 冠棘が 25 本から 28 本であること から，精巣が円形である点を除けば Euparyphium 属に所 属すると考えられる。北米産アライグマから報告された Euparyphium beaveri $[10,15]$, 本属と形態的に近似し, 本州の野生哺乳類から報告されたEchinoparyphium 
recurvatum と Isthmiophora melis $[16,17]$ などとの異同 は, 現在検討中である。なお, 今回得られた本属標本の一 部は目黒寄生虫館において登録保存された (MPM Coll. No. 19732)。

高橋吸虫ではフナ属 Carassius の各種が, またEuparyphium 属ではカエル幼生がそれぞれ代表的な第 2 中間宿 主として報告されている $[9,14]$ 。したがって，これらの吸 虫類の寄生が見られたことは，今回調べたアライグマが餌 資源としてこれらの淡水性の動物も利用していたことの証 左になると考えられる。

\section{要約}

北海道石狩地方で駆除あるいは殺処分されたアライグマ 68 頭についてその奇生蠕虫類の調査を実施したところ, 狸 蛔虫 Toxocara tanuki (検出されたアライグマの個体数 1 , 以下同様), 高橋吸虫 Metagonimus takahashii (2), 䊂口吸 虫科のEuparyphium sp. (7) が発見された。アライグマか らこれらの蠕虫類が検出されたのは初めてである。 キーワード : アライグマ, 高橋吸虫, 狸蜔虫, Euparyphium $\mathrm{sp}$, 日本

\section{謝辞}

北海道大学文学部 池田 透助手, 酪農学園大学獣医学部 寄生虫学教室の各位, 特に川添敏弘氏(現 東松浦農業共済 組合), 農林水産省, 北海道庁, 石狩支庁および空知支庁と その関連市町村の数多くの担当者（多くは石狩支庁アライ グマ被害検討協議会委員）と獣医師の方々には材料の処置 などでお世話になった。また, 目黒寄生虫館 亀谷俊也館長, 北海道大学獣医学部 奥 祐三郎助教授およびチェコ共和 国メンデル大学 Tenora,F.教授には関連の文献をご紹介 いただいた。さらに，大阪市鶴見緑地鳥類生態園(前 大阪 市立天王寺動物園）宮下 実獣医師と札幌市立円山動物園 向井 猛獣医師にはアライグマ蜔虫の標本を比較検討用に 提供いただいた。以上ここに記して深謝したい。

\section{引用文献}

1. 石狩支厅アライグマ被害検討協議会編. 1999.アライグマによる農業等
被害防止の手引き, 北海道石狩支打農業振興部農務課, 札幌.

2. Fox AS, Kazacos KR, Gould NS, Heydemann PT, Thomas C, Boyer,KM. 1985. Fatal eosinophilic meningoencephalitis and visceral larva migrans caused by the raccoon ascarid Baylisascaris procyonis. J Med 312: 1619-1623.

3. Cunningham CK, Kazacos KR, McMillan JA, McAuley JB, Wozniak EJ, Weine LB. 1994. Diagnosis and management of Baylisascaris procyonis infection in an infant with nonfatal meingoencephal itis. Clin Infec Dis 18: 868-872.

4. Kazacos KR.1986. Raccoon ascarids as a cause of larva migrans. Parasitol today 2: 253-255.

5. 宮下 実. 1993. アライグマ䖲虫 Baylisascaris procyonis の幼虫移行 症に関する研究. 生活衛生 37:137-151

6. Hartwith G. 1974. Key to genera of the Ascaridoidea. In CIH keys to the nematode parasits of vertebrates, Commonwealth Agricultural Breaux, Farnham Royal, Bucks, England.

7. Yamaguchi S. 1941. Studies on the helminth fauna of Japan. Part 35. Mammalian nematodes II. Jpn J Zool 9: 409-439.

8. Skryabin KI, Shikhobalova NP, Mozgovoi AA. 1991. Oxyurata and Ascari data. In Key to Parasitic Nematodes, Amerind Publishing Co., New Delhi.

9. Saito S, Chai JY, Kim KH, Lee SH, Rim HJ. 1997. Metagonimus miyatai sp.nov. (Digenea:Heterophyidae), a new intestinal trematode transmitted by freshwater fishes in Japan and Korea. Kor J Parasitol 35: 223-232.

10. Bafundo KW, Wilhelm WE, Kennedy ML. 1980. Geographic variation in helminth parasites from the digestive tract of Tennessee raccoons, Procyon lotor. J Parasitol 66: 134-139.

11. Hamir AN, Snyder DE, Hanlon CA, Rupprecht CE. 1993. A trematode (Phagicola sp.)-induced mesenteric lymphadenitis and enteritis in raccoons (Procyon lotor). Vet Pathol 30: 373-376.

12. Snyder DH, Hamir AN, Hanlon CA, Rupprecht CE. 1989. Phagicola angrense (Digenea:Heterophyidae) as a cause of enteritis in a raccoon (Procyon lotor). $J$ Wildl Dis 25: 273-275.

13. Williams RR, Myer DG. 1964. Metagonimoides oregonensis Price, 1931 occurring in Ohio raccoons (Trematoda:Heterop hyidae). Ohio J Sci 64: 400.

14. Schell SC. 1970. How to know the tromatodes, Wm. C. Brown Company Publishers, Iowa.

15. Cole RA, Shoop WL. 1987. Helminths of the raccoon (Procyon lotor) in West ern Kentucky. J Parasitol 73: 762-768.

16. Kamiya H, Suzuki Y. 1975. Parasites of the Japanese badger, Meles meles anakuma Temminck, especially on Isthmi ophora melis (Schrank, 1788) Luhe, 1909. Jpn J Vet Res 23: 125-130.

17. 八木沢誠. 1978. 東北地方に招ける人畜共通寄生蠕虫の研究. 弘前医 学 30: 239-284. 